\title{
Boko Haram Terrorism in Nigeria: Peace and Security Implications for the 'Giant State'
}

\author{
Opeoluwa Biao \\ Department of Political Studies, University of Cape Town
}

\begin{abstract}
This article seeks to investigate the peace and security implications for Nigeria due to Boko Haram terrorism. Boko Haram is a terrorist group in northern Nigeria that seeks the establishment of a strict sharia Islamic state in the country, as it considers the current type of government corrupt and irredeemable. In this article, we identified and explored three causes of terrorism: economic, political, and social factors. It was found that terrorism is usually the result of some perceived structural issue. Thus, the article uses thematic content analysis to evaluate Boko Haram terrorism and the implications for Nigeria. It was found that Nigeria's peace and security is severely threatened by Boko Haram and its activities. Consequently, recommendations were proffered as a means for the Nigerian government and security agencies to combat the Boko Haram threat.
\end{abstract}

Keywords: Boko Haram, Terrorism, Counterterrorism, Peace, Security,

DOI: $10.7176 / \mathrm{JAAS} / 71-01$

Publication date: April $30^{\text {th }} 2021$

\section{INTRODUCTION}

Nigeria gained political independence from British rule on 1 October 1960 (Yusuf 2017). Since then, there have been expectations from within and without the country for general socio-economic growth, peace, and security. These expectations were not unreasonable because Nigeria went into independence a blessed state overflowing with natural resources and human capital (Onyeukwu 2007). However, due to divisions along religious and ethnic lines, and the presence of venal politicians in the corridors of state power, the West African state has failed to live up to the hype. The Boko Haram terrorism that developed in the northern part of the country (Akubo and Okolo 2019), only came to compound issues and dampen the possibility for the giant state to achieve veritable peace and security. Acts of terror such as those perpetrated by the Boko Haram sect are not a compliment and go a long way in damaging not only Nigeria's internal cohesion, but its international reputation as well. Countries where peace and security is seriously threatened and undermined tend to be failed or failing states. Although it might, now be somewhat premature to assume that Nigeria is a failed state, the element of terrorism has often contributed to pulling down all states that eventually got characterised as failed states. Somalia, where Al-Shabab terrorist group holds strong (Ali 2008) is a case in point.

Although much of the territory that Boko Haram used to occupy during the Goodluck Jonathan's presidency (2010 - 2015) has now been reclaimed by the Nigerian state, the inability of the state to rid the north-eastern part of the country from the menace and attacks of Boko Haram portend imminent doom for the 'giant of Africa'. In fact, Boko Haram has already succeeded in inflicting a great damaging blow to Nigeria's international reputation when it got named as a Foreign Terrorist Organisation (FTO) by US authorities in 2011 (Committee on Homeland Security, 2011). This was after a suicide bombing attack on the United Nations (UN) headquarters in Abuja, that left 23 people dead and several others injured. Thus, the threat to Nigerian peace and security by this sect is real and needs to be addressed.

What then are the full implications of the continued existence of Boko Haram in Nigeria and what steps may be taken to surmount this peace and security challenge? It is against this backdrop that this article examines the activities of Boko Haram sect in Nigeria.

\section{METHODOLOGY}

The area of study is to examine the peace and security implications for Nigeria due to Boko Haram terrorism. Thus, data for this study was gathered using secondary sources - books, journals, relevant government documents, newspaper articles, and internet materials. Data was analysed using thematic content analysis. The study population is Nigerian.

\section{CONCEPTUAL CLARITY}

The terminologies 'terrorism', 'peace' and 'security' appear in numerous literatures with varying meanings. The below discussion lays bare the understanding of these concepts within the context of this article.

\section{Terrorism}

Terrorism can be defined as any premeditated act of violence on the part of an individual or a group, intended to cause harm and/or to make a group of people or an organisation to react in a way determined by the terrorist(s). However, there is no consensus on the meaning of the concept of terrorism. One of the reasons for the lack of a 
conceptual unanimity is that certain groups that carry out acts that are deemed 'terrorist', consider themselves freedom fighters and/or liberators (Orhero 2015). Thus, there is a conceptual difficulty in identifying true terrorist groups. However, Orhero points out that there are some agreed upon pointers of terrorism, these include: the use of illegal force, sub-national actors, political motives, unconventional methods, attacks against civilian and passive military targets, and acts aimed at deliberately affecting an audience.

Out of the abovementioned pointers, three come out as key components of a terrorist act. These are: 'illegal use of force', 'political motives', and 'acts aimed at deliberately affecting an audience'. These three factors are common to terrorist activities.

Within the family of formal definitions of 'terrorism', the proposition of the Office of the United Nations High Commissioner for Human Rights (OHCHR) readily comes to mind. That definition views terrorism as an act of violence that targets civilians in the pursuit of political or ideological aims (OHCHR 2008:5). This is a short and direct definition. However, its weakness resides within its shortness. For example, it assumes that terrorist acts are generally aimed at civilians alone. It is known that several terror attacks aim to hurt national governments and their interests both at home and abroad. Additionally, numerous terror attacks are directed at both national and international organisations and corporations. For example, although the September 11, 2001 attack tragically took the lives of countless civilian lives, yet, that attack was aimed to shake the resolve of the US government which Al-Qaeda considered a barrier to their goals (Kondrasuk, 2004).

On his part, Hoffman (1998) defines terrorism as:

..... the deliberate creation and exploitation of fear through violence or the threat of violence in the pursuit of political change .... Terrorism is specifically designed to have far-reaching psychological effects beyond the immediate victim(s) or object of the terrorist attack. It is meant to instil fear within, and thereby intimidate, a wider "target audience" that might include a rival ethnic or religious group, an entire country, a national government or political party, or public opinion in general (Hoffman 1998 as cited in Richards 2013:11-12).

From the above definition, it can be surmised that terrorism seeks to subdue its target audience psychologically by instilling fear and worry in their minds. Through this process, terrorists hope to achieve their goals. However, what Hoffman fails to indicate, is whether these conscious acts of terror are usually successful or not. Although several terrorist groups have laid claim to territories within sovereign states, rarely have terrorist organisations controlled an entire country with a view to bringing their aspirations to fruition. Therefore, even though terrorists seek to instil fear in the minds of their target audience, terrorism is usually a veil that masks weakness and anger.

Schmid and Jongman (1988:28) definition is one that is broad enough to include the main features of terrorism. It conceives of terrorism as

......an anxiety-inspiring method of repeated violent action, employed by (semi-)clandestine individual, group, or state actors, for idiosyncratic, criminal, or political reasons, whereby-in contrast to assassination - the direct targets of violence are not the main targets. The immediate human victims of violence are generally chosen randomly (targets of opportunity) or selectively (representative or symbolic targets) from a target population and serve as message generators.

The above definition is more inclusive of most features of terrorism and it remains valid today. In fact, it paints a very near perfect picture of how several terrorist organisations act. As a result of its inclusive nature, this definition of terrorism is adopted as the operational definition for this article.

\section{Peace}

Peace, in its simplest meaning, is the absence of war and strife. Additionally, peace can be construed as a state of mind where the individual is free, happy, and can achieve his or her dreams without fear or worry. Nevertheless, like many concepts in political studies, there is no unanimity on the meaning of the term. Thus, to bring some clarity on the concept, the area of peace studies was developed. Matsuo (2007) puts forth that in the forming years of peace studies, there was a general perception that peace meant the absence of war. He further advances that the reason for this conception of peace on the part of the early peace researchers, was in part because peace studies was heavily inspired by the reflections of the catastrophes of World War II (WWII) and the fact that there was a possibility of a total nuclear war between the two superpowers, the sense of crisis of human survival was brought to the front burner (Matsuo, 2005; Matsuo, 2007). Thus, the early years of peace studies focused primarily on how to avert war. Early peace studies also neglected several areas of peace research, as the trend at the time was that war was fought only among great powers or to narrow it down only by states. In turn, they ignored conflicts boiling in the developing world and internal conflicts.

Emblematic peace researcher Johan Galtung (1967) describes peace as an 'umbrella concept'. For him, it is a psychological state felt because of the attainment of certain laid out human aspirations (Olanrewaju, 2013). Put otherwise, peace is a state of balance and harmony. Galtung also talks about what he terms 'negative' and 'positive' peace. The former is the absence mutually agreed hostility, while the latter is the presence of social 
justice. Thus, positive peace is the presence of justice, equity, liberty, and all those conditions that make the life of man serene. While Galtung's conception of peace is plausible, it banks on human benevolence and wisdom, these features are rare among the general population and greed and spite in many instances cause men to act in ways to protect their interests.

On the other hand, Rummel (1981) argues that above all else, peace is that one 'thing' most sought after by humanity. He states that there is never a good war or a bad peace. For him, peace is derived from several sources (eastern, western tradition etc.). However, perhaps what Rummel ignores is the fact that especially prevalent among certain groups such as freedom fighters, terrorists etc. is the idea of a 'just war', which they are convinced is the will of God. They believe fervently that without war there can be no peace.

The definition adopted for the purpose of the current study is provided by Miller (2005:55). For him, peace is a political condition that guarantees justice and social stability through formal and informal institutions, practices, and norms. Quite a few conditions must be met for peace to be reached and maintained, they include:

- balance of political power among the various groups within a society, region, or, most ambitiously, the world - legitimacy for decision makers and implementers of decisions in the eyes of their respective group, as well as those of external parties, duly supported through transparency and accountability

- recognised and valued interdependent relationships among groups fostering long-term cooperation during periods of agreement, disagreement, normality, and crisis

- reliable and trusted institutions for resolving conflicts

- sense of equality and respect, in sentiment and in practice, within and without groups and in accordance with international standards

- mutual understanding of rights, interests, intents, and flexibility despite incompatibilities.

\section{- Security}

Security is an important concept in political studies. It is concerned with the safety and survival of states and their citizens. However, like the terrorism and peace, security is not an easy concept to define. Degaut (2015) points out that the concept has meant different things for different people throughout human history and this has added to its complexity and a lack of a consensus on its meaning. The traditional IR approach to security was in the epoch when Realism was almost unchallenged. During those times the focus of security was on the state, which was considered the main referent of security. Consequently, when realists spoke about 'security', they were referring to the territorial protection of the state rather than its populace (Moller, 2000). Thus, for realists, security is the protection and/or shielding of the state from attacks, threats, or aggression (Lin, 2011).

On the other hand, liberalists who were seemingly fed up with the dominance of Realism in IR and security studies, decided to take a different approach. Even though they accept as realists posit that the international system is anarchical, for liberalists, impasses can be resolved via dialogue and concessions rather than through violence. Thus, for liberalists, security is a goal that can be achieved via interdependence/cooperation, democratic peace, and institutions/regimes. Apart from states, liberalists focus on other important actors (Lin, 2011). In a situation such as the one occurring in northern Nigeria with the Boko Haram insurgency, liberalists recognise the need for the state to act, but also give credence to other actors such as international organisations and inter-governmental organisations (IGOs) that can contribute towards ending the acts perpetrated by such terrorists organisations. Thus, security has been divided between state and human security with the latter gaining ground after the Cold War.

Shinkaiye (2004) advances that security can be defined as the entirety of actions and measures as well as legislative and operational moves taken to guarantee peace, stability and the overall wellbeing of a nation and its people. However, the definition adopted for the current study is provided by Arnold Wolfers (1962:150), for him, security, in an objective sense, measures the absence of threats to acquired values, in a subjective sense, the absence of fear that such values will be attacked. Below, we will explore the causes of terrorism, this will allow us to navigate and understand the reason why terrorist groups like the Boko Haram are found and the motivation behind their actions.

\section{CAUSES OF TERRORISM.}

What are the real causes of terrorism? This question has been burning on the minds of scholars for quite some time. To identify the causes, this article divides them into groups; they include: the economic, political, and social factors. Under each heading we will explore several root causes of terrorism.

\section{- The Economic Factors.}

The widespread theory is that poverty causes terrorism. In effect, when people are poor and their chances of getting out of their predicament is stifled, they may then turn to violent means to express their feelings terrorism being one of such violent means. Butler (2015) opines that the poverty variable contains other smaller variables that may lead to someone being labelled as destitute. Some scholars use several factors to measure poverty levels such as social inequality, low GDP, and illiteracy (Newman 2006; Gunaratna 2004; Pedahzur, Perliger and Weinburg 2003; Butler 2015). Conversely, others employ other factors such as inflation, 
unemployment rate, and population size to measure poverty (Akhmat et al 2013; Butler 2015). Yet, what could be deduced is that poverty is an undesirable state, and when an individual is destitute, he has the potential of doing almost anything to get out of such a position.

Poverty could lead certain individuals to violence, the chance for this is heightened when the individual(s) believe that they are being marginalised and deprived of economic benefits. The notion of 'relative deprivation' was developed in the 1970s and it argues that individuals are more likely to commit violent acts if they feel that the economic redistributive process intentionally or otherwise short-changes them (Gurr, 1970; Krieger and Meierreiks 2010). As one could imagine, such a situation boils up frustration which when release is usually nasty. Thus, it is easier for terrorist groups to recruit within their ranks such disgruntled people (Krieger and Meierreiks 2010).

Also, birth rate has been pointed out as a contributor to terrorism especially on the African continent. Feldman (2009) in his work: The Root Causes of Terrorism: Why Parts of Africa Might Never Be at Peace, argues that although several African countries have small populations, many have large populations that is expected to grow even further. For example, in 2006, there were 27.7 million people in Uganda, but that number is expected to stand at 56 million by 2025 (Feldman 2009:356). What is more, for some of Africa's poorest countries such as: Chad, Niger, Mali, Guinea Bissau, Malawi, and Burundi it has been projected that their populations will triple by 2050 . This represents a worrisome threat to Africa's peace and security. As the slums continue to grow exponentially, filled with high numbers of unemployed and illiterate individuals, this becomes a grooming room for criminals and an opportunity for terrorist groups to recruit from such places where individuals are easily lured (Feldman 2009).

\section{- Political Factors}

Government repression can lead to terrorism (Butler 2015). When government policies suffocate their constituents, and when human rights are flouted, this leaves the chance open for a lot of frustrated individuals who may then turn to terrorism to vent. There has been the debate as to which political system is best equipped to deal with terrorism, so far there has not been a definite answer. However, the current writer argues that any political system can be a victim of terrorism, because terrorists rebel against democratic societies considered as being evil, and they fight authoritarian governments claiming to be doing the will of God to liberate the people. As such, terrorists only attack these systems in different ways, but no one political system could boast of being totally immune from terrorist threats.

Political change and volatility can also contribute to terrorism (Krieger and Meierreiks 2010). Political change may create a power vacuum thus making it easier for terrorist groups to push their agenda. What is more, terrorism becomes less expensive as it is difficult for a weak or fragile government to fight off terrorists. Also, supporting extremist organisations might be a trend in weak political systems because the possibility for nonviolent alternatives are drastically reduced (Krieger and Meierreiks 2010). Failed states might become academies of international terrorism, where in phases of internal chaos (e.g. civil wars) individuals can be taught how to carry out terrorist acts which they can then use elsewhere (Campos and Gassebner2009; Krieger and Meierreiks 2010).

\section{- Social Factors}

There have been arguments that social issues can contribute to terrorism. For instance, the literacy level has been mentioned by different studies (Butler 2015), but there has been no substantial proof to validate this. In fact, several top notorious terrorist leaders and chiefs are known to have been well educated. However, literacy levels can affect individual decision making and choice pattern. People with little or no education might tend to make uninformed decisions, and this could include being swayed to join a terrorist group. The Human Development Index takes into consideration per capita income, life expectancy, and education regarding terrorism, and there was the conclusion that there is a correlation between Human Development and terrorism (Schmid 2005).

Religion is another social variable of importance. In the modern world, there has been a rise in religious extremism (Butler 2015). Religious terrorism is the believe that a supernatural force or being has approved of violent acts of terror (Martin 2010). Those who engage in religious terrorism usually are of the belief that their inhumane acts here on earth, will be rewarded in the afterlife. Extremism is not constrained to just any one religion. However, in more recent times, Islamic terrorism has been on the rise (Martin 2010). Religious terrorism could be argued to be the main type of terrorism present today. Below, we will explore the Boko Haram organisation with a view of getting a sense of their mission and activities predominantly in Nigeria.

\section{WHAT IS BOKO HARAM?}

There is no consensus in the literature as to when the Boko Haram sect was founded. What is clear, however, is that it originated in Nigeria. A popular account of the group can be traced back to 2002, when Mohammed Yusuf, an alluring preacher, became its leader (Onuoha 2014). However, to the Nigerian intelligence community, the origins of the group could be traced even further back to 1995, when Abubakar Lawan founded Ahlulsunnawal' jama' ahhijra or Shabaab group (Muslim Youth Organisation) in Maiduguri, Borno State. The group started out 
as largely non-violent up until Yusuf took charge in 2002. The group has been known by various names over time such as: Hijra, Nigerian Taliban, Muhajirun etc. (Onuoha 2014).

In 2002, the sect today known as Boko Haram declared the city of Maiduguri, excruciatingly corrupt and incorrigible (Walker 2012). The group then embarked on hijra (a withdrawal as that embarked on by Prophet Muhammad from Mecca to Medina). The group moved from Maiduguri, to Kanama, Yobe state, a village near Niger Republic. There they established a separatist community run on hard-line Islamic ideologies (Walker 2012). The group is known for and got its name 'Boko Haram' for its rejection of any form of Western education. Its principal aim is to replace the secular form of governance currently in Nigeria with a government that follows to stringent Islamic sharia law (Onuoha 2014). For the group, the state of Nigeria is deplorable, and it argues that the singing of National Anthem and pledge of allegiance to the flag are signs of state worship and this deserves punishment by death (Campbell 2014). All this points to the fact that the group is notorious and extremist. The Nigerian state is considered as corrupt and exploitative of the poor, all of which are against the will of Allah. This indeed shows the hard-line nature of the group, and one can imagine that people with such ideologies and mental outlook will be willing to do anything to realize their goals. (Orhero 2015:8) describes the organisation of the group, he states that:

In terms of organization, Boko Haram has a well-organized and coordinated pattern of authority designed for attack and violence. The sect is headed by a leader with two deputies. In the states where the sect exists, there is a commander or Amir. In the local governments where they operate, there are also Amirs. Below the Local Government Area Commanders are the lots of the followers. The sect operates clandestinely, and this makes them elusive to security operatives. Their funding derives from three main sources, namely, levy by members, donations from individuals and organizations and external sources especially Al Qaeda.

Boko Haram recruits its members amongst poor children, beggars (known as Almajiris), unemployed high schools and university graduates, mainly from but not limited to northern Nigeria (Onuoha 2014). Thus, it could be argued that the group capitalises on frustrations of the poor and jobless, who are then used to carry out their raids and attacks. Interestingly, however, the group counts amongst its ranks some wealthy, educated, and influential people (Onuoha 2014). In the areas they control they extort food, property, and money from the residents which they use to sustain themselves.

The group's violent history began in 2003 when it attacked police stations and public buildings in Kanama and Geiam in Yobe State. It became an issue of more pressing concern when in 2004, youths in Borno and Yobe state withdrew from schools, tore up their certificates, and joined the group. It was in 2009 that the group's activities intensified. The group was travelling en masse to the funeral of a fellow member, when they were stopped by the police who were insisting on the use of helmets, it was unclear what happened, but an argument ensued and a member of the group fired on the police injuring several of them (Walker 2012; Onuoha 2014). That event sparked off a wave of turbulence that swept through Bauchi, Borno, Kano, Yobe, and Katsina states. The uproar came to an end on July 30, 2009, when Yusuf was captured, and after some hours in police custody, he was killed extra-judicially; with the police claiming he had tried to escape. It was reported that over 800 members of the group were killed in the revolt (Onuoha 2014).

The Boko Haram sect after the 2009 upheaval were determined to fight back, and since then there has been a violent escalation in their violent attacks. All of this points to the fact that the methods used by the Nigerian authorities during the 2009 upheaval proved to be fatal and motivated the group even more to carry out their destabilising campaign. The group went underground resurfacing in 2010 with Abubakar Shekau as its new leader (Campbell 2014; Onuoha, 2014). Shekau was Yusuf's top deputy.

Under Shekau's leadership, the organisation seemed to be even more violent, as it sought to fight the security forces and replace through violence the Nigerian state government and the compromised Islamic system. Boko Haram called for the replacement of the Sultan of Sokoto with a shura (council), made up predominantly of its members (Campbell 2014). The group appears to be more structured and organised since Shekau took over, employing new tactics such as: suicide bombing, target assassinations, drive-by shootings, and slitting of victims' throats. Of course, the adoption of such new strategies is meant to instil fear nationally and what this has shown is that the Nigerian government and its security forces are having a torrid time in trying to do away with this sect. Using these various new strategies, the group have attacked a wide ranging group of people, these include; Christians, school children, public servants, teachers, Islamic scholars and more recently as Onuoha put it, all those who do not belong to the group. Although the group's activities are concentrated in north-eastern Nigeria, it has proven to have a national reach. It has carried out activities in Plateau state where ethnic and religious tensions have been high. Also, Boko Haram claimed responsibility for a suicide bombing in the port of Lagos (Campbell 2014). In May 2012, the group attacked a Catholic church in Jos, and killed six worshippers. On Easter Sunday, they killed thirty-eight Christians as they worshipped using a vehicle bomb (Al Jazeera 2012; Orhero 2015).

To prove their disgust for Western education and culture, they have attacked and burnt down several 
learning institutions in the north-east region of Nigeria. In 2014, the sect kidnapped 276 schoolgirls from the Government Girls Secondary School in Chibok, Borno state (Orhero 2015). This incident got the attention of the international community and portrayed Nigeria as a state with an extremist problem. Former Nigerian President Goodluck Jonathan in 2014 claimed that the group since 2009 has killed over 12000 Nigerians and injured about 8000 (Onuoha 2014). What is clear, is that the group's presence poses a threat to Nigeria's peace, security, and cohesion. If allowed to continue unabated it will wreak havoc well beyond its current territorial scope and lead the Nigerian state down a dark road. The current author is in no way suggesting that getting rid or snuffing out the organisation is going to be an easy task. The ideology and structure of the organisation makes it difficult to pinpoint its members and shake its core and the killing or arresting of its leader(s) might not be a lasting solution. Below, we will explore the peace and security implications for Nigeria due to the Boko Haram terrorism.

\section{PEACE AND SECURITY IMPLICATIONS OF BOKO HARAM TERRORIST ACTIVITIES}

Since 2009, Nigeria has been trying with varied levels of success to defeat and put an end to the Boko Haram menace. In effect, the federal government of Nigeria considers the sect as a threat to the values that the country holds dear. Also, what can be gathered, is that Boko Haram seem not to be ready to give up or close shop. To this end, the group has become a serious pain in the neck of the giant West African state. Nigeria's peace and security is threatened due to the presence of Boko Haram.

To show just how the group has put in jeopardy the peace and security of the Nigerian state, in January 2012, President Goodluck Jonathan declared a state of emergency across 15 local government areas in four states in the north where Boko Haram mostly operated (Onuoha 2014). When the state of emergency ended by July 2012, the security situation had still not been addressed. This illustrates one of two things; that the sect is so well structured and organised that it is difficult to bring down or the Nigerian security forces are not implementing the right strategies to put an end to what has been a destabilisation campaign by the sect. To put a stop to the atrocities carried out by Boko Haram several 'state of emergency' have been implemented in Yobe, Adamawa, and Borno states - the states the most affected by the terrorism of the sect. Despite concerted efforts from the federal government of Nigeria to put a stop to the activities of the sect, it has still managed to destabilise and create instability and insecurity in the country. For example, in the first four months of 2014, it was reported that over 2,596 people died in terror-related attacks in Nigeria (Onuoha 2014:5). Such incidents of terror unleashed on the Nigerian state, proves that the group is determined to get what it wants and willing to commit gruesome acts to achieve its end goal - the creation of a strict sharia Islamic state. Amalu (2015) argues that the Boko Haram group has had negative peace and security implications for Nigeria. She states that due to the activities of the group, human security in the giant west African state has been severely threatened. Food and nutrition, health, shelter, education, and protection in Nigeria has been jeopardised due to the presence of Boko Haram (Amalu 2015).

The basic human needs especially in the north-east of Nigeria are not able to be met. People have abandoned their businesses and livelihoods because of fear of being killed or maimed by the notorious Boko Haram group. The sect is currently the biggest security challenge for the Nigerian government (Onuoha 2014). When people cannot sleep peacefully, work without always looking over their shoulders, worship in peace, then there is a serious challenge to the peace and security of the given state. And if such challenges are not nipped in the bud, it will escalate, and the consequences will be dire. Amalu (2015) advances that those who experience violent crimes, tend to suffer from various forms of affective disorders. In effect, apart from the physical results of the Boko Haram terrorism, people who have witnessed or have been maimed by the group might find it difficult to stop reliving such instances in their minds. This is a huge disruption to peace and security, as it does not just concern the protection of states from aggression, but the constituents as well from violent threats.

In a study carried out by Chukwurah et al (2015), it was found out that before the emergence of the Boko Haram group, the economy of the north was vibrant and bubbling. This was crucial as a sort of synergy is needed between the economies of all the regions of Nigeria for the country to truly develop in a peaceful and secure manner. However, since the appearance of Boko Haram on the Nigerian scene, things have taken a bad turn for the country, and even some argue for neighbouring states (Onuoha 2014). The transport, infrastructural, commercial, tourism, and agricultural sector of northern Nigeria has been dealt a severe blow by the Boko Haram menace (Chukwurah et al 2015). The group has disrupted the peace and security of not just northern Nigeria but the entire country. Even when one tries to find out if any positives have been made in regards to the peace and security of Nigeria since the appearance of Boko Haram, what can be gathered is that the country will be a much organised, coherent, peaceful and progressing state without Boko Haram in the frame. Thus, certain scholars argue that it will take years for the north (the region the most affected by the Boko Haram menace) to recover from the effects of the group's activities (Chinedu 2012 in Chukwurah et al 2015). Also, it has been advanced that the effects of Boko Haram activities on Nigerian peace and security if left unabated will result in the attainment of the status of 'failed state'. The implications are such that whichever way one looks at it, Boko Haram has turned Nigeria to a state under pressure - no one knows when the terrorists will strike and causes a 
strain on national peace and security. Orhero (2015) argues that due to the group's activities, there is an impression that Nigeria is unsafe even for ordinary visits. According to the Global Peace Index, between 2011 and 2012 there has been an acute chute of peace in Nigeria, as the west African state dropped four places to $146^{\text {th }}$ out of 158 countries in the global peace ranking (GPI 2012; Orhero 2015).

What is more, Boko Haram terrorism may lead to the abandonment of certain national aspirations on the part of Nigeria. It is clear that sub-regional and regional states will not be willing to follow a 'leader' that cannot guarantee peace and security within its own borders - when you are blind you cannot lead the search, in this case the quest for regional peace, security, and development. In the final analysis, whichever way one looks at it, the Boko Haram sect and its destabilising activities has weakened the Nigerian state locally and internationally - by this it is meant that at home Nigeria has been made to pay the costly price due to the group's presence, and abroad Nigeria has lost economic opportunities. Thus, this study found out that Boko Haram is a huge impediment to the attainment of peace and security in the giant west African state.

\section{CONCLUSION}

Due to the presence of the Boko Haram sect, Nigeria has been terrorised. Nigerians especially in the northern region of the country live in constant fear and worry. As could be deduced, such a situation disrupts the flow of everyday life and is a threat to national peace and security. The Nigerian government and its security forces have tried with varied levels of success to get rid of the sect, however, it has proven tougher than envisaged. This paper found that because of Boko Haram, Nigeria is not peaceful and secure. Also, we explored the causes of terrorism and found that in most cases it was a result of certain structural problems. Consequently, certain issues such as corruption, and a sense of marginalisation led to the establishment of the sect and its violent methodology. If this threat to the country's peace and security is left unchecked, it could lead it to a dark and bleak place. Below, the current author proffers recommendations that the Nigerian government can employ to face the Boko Haram threat.

\section{RECOMMENDATIONS}

The following are the recommendations of this article to the Nigeria government in its fight against the Boko Haram group:

- Working in concert with foreign states with greater counter-terrorism capacities:

Terrorism is not unique to Nigeria alone; it is a global conundrum. Although the main area of focus for Boko Haram is northern Nigeria, the national government and its security forces need to liaise and work in concert with other states to deal with the group. Foreign countries with much better intelligence gathering capabilities and military technology should be contacted by Nigeria to aid in this fight against Boko Haram terrorism. However, it may not just be enough to liaise with these foreign states with better terrorism fighting capabilities, the Nigerian security forces need to learn and be innovative in finding new ways than those already explored in fighting the sect. In the past, the Nigerian security forces have engaged in extra-judicial killings of captured members or suspected members of Boko Haram, and this has only fuelled the violent nature of the group. Thus, in future engagements the Nigerian government should, rather than extra-judicially kill the captured members, in the most practical way source out key information from them on how to bring down the group. As arduous as this may be, it is not impossible.

- Address structural national issues:

One of the banes of the Nigerian state is its rife corruption. This issue is widespread especially in the government structure of the country. Due to corruption the state is not run properly, and its institutions are not functioning optimally. If this issue is not effectively addressed, it will continue to be one of the reasons Boko Haram strikes. A corrupt society leaves holes for all sort weeds to grow.

Apart from the need to address the rife corruption in Nigeria, the issue of marginalisation should also be worked on. The northern part of the country has for some time had this feeling that it is being side-lined by the rest of the country. This region has the most illiterates, more destitute people are found in the north than in the southern part of Nigeria, and it is the most underdeveloped region of the country. If these issues are constantly swept under the carpet by the Nigerian government, it will end up cooking up problems for itself.

\section{- The need of a unifier leader:}

Even though some scholars argue that Nigeria is divided along ethnic and religious lines, in the 60 years of the country it has not had a true 'unifying' leader - someone charismatic who will make the country understand and feel that they are indeed one nation. The presence and actions of a unifier leader will be such that citizens will consider themselves as Nigerian first before identifying as Igbo, Yoruba, Edo, or Hausa and brothers and sisters before seeing them as Christian or Muslim. With that in place there will be a drastic reduction in the need to cause violence in the name of ethnicity or religion. 


\section{References}

Akubo, A. A., \& Okolo, B. I. (2019). Boko Haram Insurgency in Nigeria: Implications for national security and restorative justice. ACCORD.

Ali, A. M. (2008). The Al-Shabaab Al-Mujahidiin-A Profile of the First Somali Terrorist Organisation. ISPSW.

Amalu, N. S. (2015). Impact of Boko Haram insurgency on human security in Nigeria. Global Journal of Social Sciences, Vol. 14.

Butler, T. (2015). What causes terrorism

Campbell, J. (2014). Boko Haram: origins, challenges and responses. NOREF.

Chukwurah, C. D., Eme, O., \& Ogbeje, E. N. (2015). Implication of Boko Haram terrorism on northern Nigeria. Medittereanean Journal of Social Sciences.

CommitteeonHomelandSecurity. (2011). Boko Haram: Emerging threat to the US Homeland. Washington DC: US government printing office .

Degaut, M. (2015). What is security? . Research Gate .

Feldman, R. L. (2009). The Root Causes of Terrorism: Why Parts of Africa Might Never be at Peace. Routledge.

Galtung, J. (1967). Theories of Peace: A Synthetic Approach to Peace Thinking. . Oslo: International Peace Research institute.

Kondrasuk, J. N. (2004). The Effects of 9/11 and Terrorism on Human Resource Management: Recovery, Reconsideration, and Renewal. Employee Responsibilities and Rights Journal, Vol. 16, No. 1.

Krieger, T., \& Meierrieks, D. (2010). What causes terrorism. Springer Science+Business Media, LLC 2010.

Lin, L. S. (2011). STATE-CENTRIC SECURITY AND ITS LIMITATIONS: THE CASE OF TRANSNATIONAL ORGANIZED CRIME . RESEARCH INSTITUTE FOR EUROPEAN AND AMERICAN STUDIES.

Martin, G. (2010). Religious Terrorism. In G. Martin, Essentials of Terrorism: Concepts and Controversies. SAGE PUBLICATIONS.

Matsuo, M. (2007). Concept of Peace in Peace Studies: A Short Historical Sketch . Institute for Peace Science, Hiroshima University.

Miller, C. E. (2005). A GLOSSARY OF TERMS AND CONCEPTS IN PEACE AND CONFLICT STUDIES. Addis Ababa: University for Peace.

Moller, B. (2000). THE CONCEPT OF SECURITY: THE PROS AND CONS OF EXPANSION AND CONTRACTION. Tampere: IPRA.

OHCHR. (2008). Human Rights, Terrorism and Counter terrorism . Geneva : Office of the United Nations Commissioner for Human Rights .

Olanrewaju, P. I. (2013). The Conceptual Definitions of Peace and Conflict. Ota.

Onuoha, F. C. (2014). A danger not to Nigeria alone - Boko Haram's transnational reach and regional responses. Freidrich-Ebert Stiftung.

Onyeukwu, A. J. (2007). Resource Curse in Nigeria: Perceptions and Challenges . Centre for Policy Studies .

Orhero, A. E. (2015). The Economic and Security Implications of Boko Haram Terrorism . International Journal of African and Asian Studies .

Richards, A. (2013). Conceptualizing Terrorism. Studies in Conflict and Terrorism 37 (3), 11-12.

Rummel, R. J. (1981). UNDERSTANDING CONFLICT AND WAR: VOL. 5:

Schmid, A. (2005). Prevention of Terrorism . In T. Bjorgo, Root Causes of Terrorism: Myths, reality and ways forward. Routledge .

Schmid, A. P., \& Jongman, A. J. (1988). Political Terrorism: A New Guide To Actors, Authors, Concepts, Data Bases, Theories, And Literature. Amsterdam : Transactions Books.

Shinkaiye, J. K. (2004). Stategic Defence Matters and Future of Democracy in Nigeria. NIPSS.

Walker, A. (2012). What is Boko Haram. United States Institute of Peace.

Wolfers, A. (1962). National Security as an Ambiguous Symbol. Baltimore: Johns Hopkins University Press.

Yusuf, H. (2017). Nigeria: the colonial legacy and transitional justice. CSVR. 